Xavier University

\title{
Exhibit
}

\section{Hungry Hearts and Broken Dreams at the Springsteen Motel}

\section{Graley Herren}

Xavier University

Follow this and additional works at: https://www.exhibit.xavier.edu/english_faculty

Part of the English Language and Literature Commons, and the Music Commons

\section{Recommended Citation}

Herren, Graley, "Hungry Hearts and Broken Dreams at the Springsteen Motel" (2020). Faculty Scholarship. 597.

https://www.exhibit.xavier.edu/english_faculty/597

This Article is brought to you for free and open access by the English at Exhibit. It has been accepted for inclusion in Faculty Scholarship by an authorized administrator of Exhibit. For more information, please contact exhibit@xavier.edu. 


\section{Hungry Hearts and Broken Dreams at the Springsteen Motel}

\section{GRALEY HERREN}

Xavier University

ABSTRACT: Over the course of his career, Bruce Springsteen returns to certain characters and preoccupations that he first chronicled in his album The River. One recurring scenario involves a man in a committed relationship who becomes dissatisfied, meets a woman at a bar, has an affair (sometimes at a nearby motel), and in the process blows up his seemingly stable life. Each time Springsteen returns to this scenario he offers interesting variations that evolve in perspective and tone. This article charts a musical road trip, beginning with "Hungry Heart" and "Stolen Car" on The River, descending into "One Step Up" on Tunnel of Love, detouring down "Highway 29" on The Ghost of Tom Joad, and culminating at the "Moonlight Motel" on Western Stars. It is a journey encompassing love and loss, faith and betrayal, self-knowledge and self-destruction, and the insatiable hunger for something to fill the void in the directionless lives of his characters.

KEYWORDS: Bruce Springsteen, The River, Tunnel of Love, The Ghost of Tom Joad, Western Stars

The philosopher Heraclitus famously claimed that one can never step into the same river twice. ${ }^{1}$ Stick a toe into your local waterway and repeat the 
process forty minutes later, or forty days or forty years, and it won't be the same as before. The flowing river will have moved and changed in that time and so will you. Heraclitus used this image to illustrate his doctrine of universal flux. It's worth keeping this maxim in mind as we dip back into Bruce Springsteen's The River. In one sense this milestone double-album is fixed forever in the vinyl of 1980. In another sense, however, one can never return to the same The River. Springsteen has continued to mature and evolve as an artist, and his audience has moved and changed with him. Heraclitus was right, and so was T. S. Eliot when he claimed that old art is retroactively transformed by the new art that follows it. ${ }^{2}$ Springsteen could not have known where his river was flowing forty years ago, but in hindsight we can see where it led, and that knowledge of his evolving artistic trajectory inevitably alters what we hear and how we respond to the earlier work today.

Something keeps sending Springsteen down to The River again and again. Call it thematic consistency or compulsive repetition, he keeps returning to certain characters and preoccupations that were first chronicled in The River. One recurring scenario is worth examining in detail because it keeps luring Springsteen himself back, across the decades and through multiple songs: a man in a committed relationship becomes dissatisfied, meets a woman at a bar, has an affair (sometimes at a nearby motel), and in the process blows up his seemingly stable life. Each time Springsteen returns to this scenario he offers interesting variations that evolve in perspective and tone over the course of his career. This article charts a musical road trip, beginning with "Hungry Heart" and "Stolen Car" on The River (1980), descending into "One Step Up" on Tunnel of Love (1987), detouring down "Highway 29" on The Ghost of Tom Joad (1995), and culminating at the "Moonlight Motel" on Western Stars (2019). It is a journey encompassing love and loss, faith and betrayal, self-knowledge and self-destruction, and the insatiable hunger for something to fill the void in these characters' directionless lives.

The prototype is established with "Hungry Heart." In his autobiography Born to Run, Springsteen observes, "The River would be my first album where love, marriage and family would cautiously move to center stage." ${ }^{3}$ It would still be several years before he plunged into his first marriage, but Springsteen was already imagining his way into marital 
dysfunction in "Hungry Heart." The first verse succinctly summarizes the arc of a failed relationship:

Got a wife and kids in Baltimore, Jack

I went out for a ride and I never went back

Like a river that don't know where it's flowing

I took a wrong turn and I just kept going ${ }^{4}$

I'm intrigued by that mention of "Jack." Springsteen often inserts a generic addressee in the form of "mister," "sir," "son," or "buddy." But this reference to Jack sounds specific, like the singer is actually recounting his story to someone in particular, probably a bartender or fellow lounge lizard. Or it could be a soliloquy to the shot of Jack Daniels sitting in front of him. Whiskey can't control where it's flowing any more than rivers; both streams are directed by other forces. The singer likewise simply goes with the flow, surrenders to instinct, and follows his heart wherever it leads, from one wrong turn to the next.

Speaking of wrong turns, I have always been a bit confused by the middle verse of "Hungry Heart":

I met her in a Kingstown bar

We fell in love I knew it had to end

We took what we had and we ripped it apart

Now here I am down in Kingstown again

Who is the "her" here? Is this backstory for the first verse, reporting how the narrator first met his wife in a bar in Kingstown (a suburb of Baltimore), describing how they loved each other before they "ripped it apart"? If so, it's telling that he retreats back to Kingstown after leaving her. Maybe he's just from that neighborhood. But a more pathetic interpretation would be that, having met his last lover in a Kingstown bar, his only game plan is to circle back to the same pickup joint and try to pick up where he left off, searching for his next Mrs. Right (or Miss Right Now). "Same old story, same old act / One step up and two steps back." 
The most convincing interpretation is that the subject of the middle verse is the narrator's new lover, the woman he left his wife for. He is married, but he is also a pretender still on the prowl. Then he meets this stranger in a bar who is doing the same. They both have hungry hearts and are eager to indulge their appetites. Springsteen's barflies give each other a buzz, and in the process they rip their home lives apart. People claim to want safety and security: "Everybody needs a place to rest / Everybody wants to have a home." And yet. Gnawing against the aspiration for tranquility and stability is a hunger for adventurous anarchy, a self-destructive counter-impulse to fuck everything up.

Consider the central image of "Hungry Heart." When we think of hunger, we typically think of the stomach. You get hungry, you find food, you consume it, and you're satisfied-for a while. But it doesn't take long for the full stomach to become empty again. Time to stalk the next prey in an endless pursuit to appease the stomach's insatiable appetite. According to this song, the heart works the same way. Driven by desire, the heart hungers for love; but like the stomach it can never remain content for long before chasing after its next meal.

It's hard to feel sorry for the singer in "Hungry Heart," not only because he is the author of his own troubles but also because his song is so upbeat and catchy. How bad can his troubles really be if they inspire us to shake our asses and sing along every time "Hungry Heart" comes on? The same cannot be said of "Stolen Car," the subdued companion piece to "Hungry Heart." Positioned on the darker second disc of The River, this dirge delivers a more somber, reflective, even nihilistic treatment of the same scenario. The entire life of a marriage, from birth to death, is condensed down into the compact opening verse:

I met a little girl and I settled down

In a little house out on the edge of town

We got married and swore we'd never part

Then little by little we drifted from each other's heart

In "Hungry Heart" the singer is ravenous for his next lover. It may be perverse, but there's also a ruthless simplicity to such predatory 
appetites: an object of desire is pursued, obtained, consumed, and then the hunt resumes for the next object of desire. But the situation is not so simple for the desolate singer in "Stolen Car." He's slipped off track but doesn't know why:

At first I thought it was just restlessness

That would fade as time went by and our love grew deep

In the end it was something more I guess

That tore us apart and made us weep

The "something more" in this context ends up sounding like something less, as if this singer's hungry heart is the result of a starvation diet.

Does the singer in "Stolen Car" leave his wife for another woman? The song never says. The only potential clue pointing in that direction comes in the lines, "I'm driving a stolen car down on Eldridge Avenue / Each night I wait to get caught but I never do.” There is an Eldridge Avenue on the outskirts of Middletown, New Jersey, Steve Van Zandt's hometown. But you couldn't do much driving on this residential avenue only five blocks long. Eldridge Avenue could be the address of a secret lover. However, it's most likely the narrator's own address for the "little house out on the edge of town." Marriage: check. Home: check. Decent neighborhood: check. So, what has him cruising the streets each night?

Unlike his counterpart on disc one, the guy in "Stolen Car" doesn't seem to be motivated by lust. His hungry heart is more like that of Kafka's hunger artist, a spiritual anorexic for whom no sustenance will ever suffice. So he feeds upon emptiness.

I'm driving a stolen car on a pitch-black night

And I'm telling myself it's gonna be alright

But I ride by night and I travel in fear

That in this darkness I will disappear

Anyone who has read Born to Run will recognize different sides of the author represented in the two main characters of "Hungry Heart" and "Stolen Car." Springsteen could sometimes be a barroom Don Juan, 
but at other times he could be an aloof misanthrope. Recalling the past relationships that formed the backdrop of The River, he writes, "It was rarely the women themselves I was trying to get away from. I had many lovely girlfriends I cared for and who really cared for me. It was what they triggered, the emotional exposure, the implications of a life of commitments and family burdens. ... With the end of each affair, I'd feel a sad relief from the suffocating claustrophobia love had brought me. And I'd be free to be ... nothing . . again." "This hunger for nothingness is reflected in "Stolen Car." There the lonely searcher isn't looking for sexual release; he's looking for release into oblivion.

$\mathrm{He}$ also seems to be looking for confession and atonement. "Each night I wait to get caught but I never do." He is a criminal, or so he tells us, repeatedly referring to his stolen car. Perhaps his desperation led him to grand theft auto. But I'm not so sure. The sins that eat away at his conscience seem to be crimes of the heart, and the stolen car may be metaphorical rather than literal. This lost soul is driving around in a stolen identity, leading somebody else's life. He tries to become the kind of person who can be satisfied with a stable family in a suburban home. For a while he pulls off the charade. But his soul's not in it; he's a criminal at heart. This ghost is trapped in the wrong machine and headed toward obliteration.

Springsteen identifies "Stolen Car" as the precursor to his 1987 album Tunnel of Love. "That song's character, drifting through the night, is the first to face the angels and devils that will drive him toward his love and keep him from ever reaching her. This was the voice that embodied my own conflicts." In the midst of his own marital turmoil, Springsteen returns to the scenarios of "Hungry Heart" and "Stolen Car" and further complicates them with "One Step Up." Unlike his forerunners on The River, the main character of "One Step Up" is still with his wife at the song's beginning. But everything else in his life is breaking down, and one expects his marriage will be next:

Woke up this morning, the house was cold

Checked out the furnace, she wasn't burning

Went out and hopped in my old Ford

Hit the engine but she ain't turning 
We've given each other some hard lessons lately

We ain't learning

We're the same sad story, that's a fact

One step up and two steps back

With no burning, no turning, and no learning, this narrator seems headed into the dark tunnel of love toward an emotional smashup like those depicted on The River.

The couple splits up between verses one and two, though Springsteen is very subtle in communicating the separation. The second verse begins with a resonant image of solitude: "Bird on a wire outside my motel room / But he ain't singing." If you're like me you can't hear "bird on a wire" without thinking of the great Leonard Cohen song "Bird on a Wire" and its emblematic free bird. Springsteen's narrator likewise yearns to spread his wings and be free, but the fact that his bird ain't singing doesn't sound encouraging. More discouraging still is the bird's location: "Bird on a wire outside my motel room." Motel? Apparently, he's no longer living at home, or he's having an affair, or both. From "One Step Up" onward, motels become essential ingredients in Springsteen's treatment of this recurring scenario.

Let's pause to muse upon the humble motel. What distinguishes a motel from a hotel? Broadly speaking, a hotel is fancier, more expensive, and more exclusive. A motel is cheap, modest in scale, probably a bit rundown, drab, and dingy. The "mo" refers to motorway: it's a place to temporarily get off the road, an affordable rest stop for the night. Or at least that's its official function. Unofficially, motels are the scenes of crimes. They have become uniquely associated with all manner of sordid activity. Who goes to a motel? Someone who needs a cheap place to do something they shouldn't be doing. It's where you go to have an affair. It's where you go to score drugs. It's where you go when you're on the run and need a hideaway from the law, or from anyone else who might be looking for you and probably wouldn't think to look in this dump. A motel is more (or less) than a place: it's an existential condition, a nowhere in which you can be nobody, where the rules and demands of so-called normal life are suspended. It's not just that you can easily assume an alias and get away with bad behavior there. Motels exist 
precisely for that purpose, as catalysts and co-conspirators. They enable transgressions and host them in appropriately squalid settings. Humans being what they are and doing what they do, there must be an alternate elsewhere, a box-set stage where we can play at being those other people and doing those forbidden things and crossing those taboo borders. The name given to such a place is "motel." Oh, and there also needs to be a bar nearby. This bar serves as audition room for the seedy performances mounted next door. Check and check please:

There's a girl across the bar

I get the message she's sending

Hmm she ain't looking too married

Me well honey I'm pretending

One step up to the bar and two steps back to the motel. There's a well-worn path connecting them.

The narrator of "One Step Up" is more ambivalent than his predecessors. He is fueled by the same carnal urges we find in "Hungry Heart," but he also suffers from the scruples of "Stolen Car." This character feels an impulse toward destruction, yet he is reluctant to blow up his life. He wishes he were the kind of man who would never do such a thing:

It's the same thing night on night

Who's wrong baby who's right

Another fight and I slam the door

On another battle in our dirty little war

When I look at myself I don't see

The man I wanted to be

Somewhere 'long the line I slipped off track

I'm caught moving one step up and two steps back

At the end of the song Springsteen finds a moving image to capture this character's inner dilemma between staying and going. The refrain of conflicted progress and regress ("one step up and two steps back") is transfigured into a symbol of harmony in the form of a dance: 
Last night I dreamed I held you in my arms

The music was never ending

We danced as the evening sky faded to black

One step up and two steps back

This poignant vignette offers some hope that their "dirty little war" might end peacefully. Unfortunately, it was only a dream. And it was last night. Tonight he's in the bar rehearsing with his next leading lady, preparing for their opening- and closing-night performance at the Bird on a Wire Motel. He has tried in his way to be free, but he slipped off track. This bird has flown. ${ }^{8}$

The next destination on our road trip follows "Highway 29" from 1995's The Ghost of Tom Joad. All the previous legs of the journey began with the protagonist's home life. This song opens instead at work, featuring a bored shoe salesman and an alluring customer. Not surprisingly, the plot soon detours into the forbidden zone:

I slipped on her shoe, she was a perfect size seven

I said "There's no smoking in the store ma'am"

She crossed her legs and then

We made some small talk, that's where it should have stopped

She slipped me a number, I put it in my pocket

My hand slipped up her skirt, everything slipped my mind

In that little roadhouse on Highway 29

We've been down this road before. In case you don't know, Jack, US Route 29 begins in Baltimore. So "that little roadhouse on Highway 29" can't be far from the Kingstown Bar in "Hungry Heart." While we've got our maps out, I should note that US Route 29, which ends in Florida, could not possibly take this couple to the "little desert motel" as specified in the third verse. This may sound like we've caught Springsteen in a wrong turn. But trust the Boss to have done his homework: Mexican Federal Highway 29 begins just south of the Texas border, and sure enough it runs south, like the song says, "into the Sierra Madres 'cross the borderline." 
Such precise details seemingly root the song in firm geography, but the true setting may be more ethereal. A surreal aura envelops "Highway 29," making it difficult to distinguish reality from fantasy. Allegedly, after the couple crosses their first line in a roadhouse affair, they acquire a taste for depravity, racing at breakneck speed across other borders on a taboo-trampling spree:

It was a small town bank, it was a mess

Well I had a gun, you know the rest

Money on the floorboards, shirt was covered in blood and she was crying

Her and me we headed south on Highway 29

We do know the rest. We've seen it in movies-Bonnie and Clyde and Badlands come first to mind-and you just know that the narrator of "Highway 29" has seen those movies, too. How exciting to follow vicariously in their footsteps. What an adventure to have a reckless affair, hitting the road with a femme fatale, stopping only for robbery, murder, and sex, then going out in a blaze of glory. You can't start a fire without a spark, right? Or maybe he's just dancing with himself in the dark. Possibly the only time he spoke to this attractive customer was when he asked her to grind out her cigarette with her perfect size seven, and everything else was just a Walter Mitty wet dream.

Just like cars, bars, and motels, dreams become indispensable ingredients in this subgenre of Springsteen songs. The "One Step Up" singer introduced the fantasy element with his dream about dancing in the dark: "We danced as the evening sky faded to black." The dreamlike quality becomes all-pervasive in "Highway 29." Dreams are explicitly referenced twice in the lyrics. The first is ostensibly a disclaimer:

In a little desert motel, the air was hot and clean

I slept the sleep of the dead, I didn't dream

I woke in the morning, washed my face in the sink

We headed into the Sierra Madres 'cross the borderline 
He claims that he didn't dream, but the song suggests otherwise with some sly wordplay. Springsteen is far too careful a writer to have accidentally repeated the word "slipped" four times in the first verse: "I slipped on her shoe"; "She slipped me a number"; "My hand slipped up her skirt, everything slipped my mind." I think he's intentionally using "slipped" to gesture toward its near homonym "slept," which he slips into the middle verse: "I slept the sleep of the dead, I didn't dream." So he says, but it sounds like he's sleepwalking through this entire scene. The second explicit dream reference comes after the couple's wreck on the highway: "The road was filled with broken glass and gasoline / She wasn't saying nothing, it was just a dream." Does he mean that it seems too bizarre to be real? Or has he slipped again and admitted that this wild ride has all been a dream?

As psychoanalysts, shamans, and artists have long recognized, dreams are capable of revealing deep hidden truths about the dreamer. The clearest instance of self-realization comes as the singer's mind wanders while driving away from the motel:

The winter sun, shot through the black trees

I told myself it was all something in her

But as we drove I knew it was something in me

Something had been coming for a long, long time

And something that was here with me now on Highway 29

Whether he dreamed it or whether it's real, he has discovered an important truth about himself. He can't blame her or anyone else for his hidden drives toward sex, violence, and death. He wanted this, whatever this unnamable something is, even if he didn't know until he tried the fantasy on for size. You can find Highway 29 on a map, but you'd be looking in the wrong place, since this song follows an internal journey into the protagonist's hungry heart of darkness. In a spoken introduction to "Highway 29" before an April 1996 performance, Springsteen told the audience that "it's a song about self-knowledge coming too late... which is when it usually comes, unfortunately, after you've fucked up." 
The singer's moment of self-knowledge is followed immediately by a fatal car crash. The final lines are both chilling and sublime:

Wind come silent through the windshield

All I could see was snow and sky and pines

I closed my eyes and I was running

And I was running then I was flying

Springsteen's artistic touches are flawless here. He doesn't have to tell us they crashed: it just happened, in an instant, without explanation or exposition, like all the other unforeseen swerves in this song. He also doesn't tell us they both died; we simply know that she isn't moving and that he ends with an out-of-body experience. If the song is a dream, then this conclusion sounds like the ending of Richard Linklater's film Waking Life, where the dreamer floats up looking for an exit from his slumber. If the song is not a dream, then the singer achieves through death the kind of freedom he never found in his dead-end life. Either way, he begins with feet on the ground-he literally sells shoes-but ends with wings. This bird has flown, too, searching for his beautiful reward.

The final stop on this musical road trip is "Moonlight Motel," the last song on Western Stars (2019). The first song, "Hitch Hikin', sets the rules of the road. It physically transports the hitchhiker, and mentally transports the listener, out West, the setting for each installment in this short-story album. "Hitch Hikin" establishes Springsteen's intertextual approach on Western Stars. He uses previous iconic images and pop-cultural allusions as vehicles, hitching rides to carry his new songs out West and into the past. He primarily bums lifts from California country-rock and Western ballads of the Sixties and Seventies, especially the music of Jimmy Webb and Glen Campbell. But he thumbs rides on the left side of the road, too. For instance, there are far too many nods toward the Rolling Stones to be coincidental. "Hitch Hikin"” contains the line "I'm a rolling stone just rolling on," and later there's a song actually titled "Stones." "Chasin' Wild Horses" unmistakably recalls "Wild Horses" off the Stones' Sticky 
Fingers album. Finally, the closing track on Western Stars, "Moonlight Motel," sounds awfully similar to "Moonlight Mile," the finale on Sticky Fingers.

By far the biggest influence on Western Stars is the myth of the American West as portrayed in countless Hollywood Westerns. ${ }^{10}$ The ghosts of John Ford, John Wayne, and Steve McQueen still ride the ranges and nurse hangovers in the film-set trailers of Western Stars, where Springsteen's album joins other recent Westerns by the Coen Brothers and Quentin Tarantino as part nostalgic reverie and part revisionist history. Even before signing the register at the Moonlight Motel, we know the place. It is a pastiche of countless cinematic Western motels: from the Bates Motel where Janet Leigh gets slashed in Psycho to the Cactus Motel where Cybill Shepherd loses her virginity in The Last Picture Show; from the Whole Year Inn where Nicholas Cage begins drinking himself to death in Leaving Las Vegas to the Union Avenue Motel where Matt Dillon shoots up in Drugstore Cowboy; from the series of Bukowski-inspired LA motels in Barfly to the various desert motels scattered across No Country for Old Men. And of course we've looked through the peephole of multiple Springsteen songs to spy on the drifters who inhabit such motel rooms, either to temporarily escape their lives or to permanently destroy them.

Like a dream, or like a movie from the City of Broken Dreams, Springsteen's motel is bathed in the neon-infused moonlight of memory and myth, and assembled from familiar fragments, lending the place an uncanny sense of déjà vu and locating it in some middle region between the past and the present. When the listener is first introduced to the Moonlight Motel, it is already boarded up. But for the narrator the place functions as a time machine, instantly transporting him back to his first visit:

Well there's a place on a blank stretch of road where

Nobody travels and nobody goes and the

Deskman says these days 'round here

Well two young folks could probably up and disappear into

Rustling sheets, a sleepy corner room 
Into the musty smell

Of wilted flowers and lazy afternoon hours

At the Moonlight Motel

There is no "warm smell of colitas rising up through the air" like at the Hotel California. Patrons of the Moonlight Motel had to settle for the musty smell of wilted flowers (a wink at the Stones' "Dead Flowers" on Sticky Fingers?). The amenities sucked, but the place served its purpose as a nowhere where two young nobodies could hide away and rustle the sheets for a few hours.

That was then. One cannot step into the same motel twice, however. The place has deteriorated into the Memento Mori Motel, a dead relic: "Now the pool's filled with empty, eight-foot deep / Got dandelions growing up through the cracks in the concrete / Chain-link fence half-rusted away." It's is a graveyard now, but the spectral traces of dead affairs still cling to the place. The narrator resurrects these spirits on his return:

Your lipstick taste and your whispered secret

I promised I'd never tell

A half-drunk beer and your breath in my ear

At the Moonlight Motel

The singer doesn't reveal her secret or his own, not directly. With the previous songs in the cycle for guidance, however, we can follow the breadcrumbs back to the source.

There are two keys to unlock this song, one for understanding why the singer visited the Moonlight Motel in the first place, and another for understanding why he makes the return pilgrimage all these years later. The first key turns in the song's bridge:

Well then it's bills and kids and kids and bills

And the ringing of the bell

Across the valley floor through the dusty screen door

Of the Moonlight Motel 
The implication is that, unlike his predecessors in the song cycle, this protagonist never left his wife and family. He answered the bell and served his time dutifully. He was driving a stolen car, but he never got caught and he never crashed. What helped him get through his straight life was the crooked life he led at the Moonlight Motel, the rendezvous spot where he could temporarily escape with his secret lover. There is no indication that he regrets or renounces the life, or rather the lives, he led. But it is clear that his hook-up days are over.

The second key to unlocking the singer's return to the Moonlight Motel is the death of his secret lover. In a scene reminiscent of the dancing dream in "One Step Up," he reports,

Last night I dreamed of you my lover

And the wind blew through the window and blew off the covers

Of my lonely bed, I woke to something you said

That it's better to have loved, yeah, it's better to have loved

Maybe everything that dies someday comes back, but it only comes back in memories and dreams. The Moonlight Motel is closed and his secret lover is departed, but the narrator's hunger for both has never diminished. For all we know, he remains true to the "bills and kids and kids and bills" to this day. But he also remains faithful to his infidelities at the Moonlight Motel. He is devastated by the loss of his lover, so much so that he can't even bring himself to repeat her ghost's full message from the dream: "It is better to have loved and lost than never to have loved at all." He can't say it, but he certainly believes this affirmation of love and honors it like a sacred vow. In fact, that dream seems to be the impetus behind his return to their motel.

He comes to perform a makeshift ritual, part posthumous wedding and part wake. He solemnly commemorates his lost love and their home-away-from-home:

I pulled a bottle of Jack out of a paper bag

Poured one for me and one for you as well

Then it was one more shot poured out onto the parking lot

To the Moonlight Motel 
"One step up and two steps back" morphs into two down and one to go. Here we complete the circuit from East to West, sunrise to sunset, youth to old age; from the Baltimore Jack of "Hungry Heart" to the bottle of Jack in a condemned motel parking lot. After the bars close and the lovers whisper their last secrets, Springsteen finds a new yet strangely familiar place to dwell: down at the end of Lonely Street at Moonlight Motel.

Western Stars is a career retrospective culminating with a wistful elegy. "Moonlight Motel" reminds me of the last great poem by W. B. Yeats, "The Circus Animals' Desertion." Yeats falls back on a time-honored poetic conceit: if you can't think of anything to write about, then write about your inability to write. The poem begins:

I sought a theme and sought for it in vain,

I sought it daily for six weeks or so.

Maybe at last being but a broken man

I must be satisfied with my heart, although

Winter and summer till old age began

My circus animals were all on show,

Those stilted boys, that burnished chariot,

Lion and woman and the Lord knows what. ${ }^{11}$

Old Yeats compares his previous characters to circus animals, and he fondly recalls the glory days when Wild Willie's Circus was running at full speed. Yeats's great gift, and the same is true of Springsteen, was in taking the stuff of personal experience, moral conviction, spiritual meditation, hawk-eyed observation, and open-hearted empathy and transmuting this raw material into art.

Listening to "Moonlight Motel," one senses that we're hearing not only the main character but also Springsteen himself reflecting back with love and devotion upon the flawed, restless, damaged, but oh-so-human characters he has created in this song cycle. These figures struggle with their desires and fears, groping to figure out who they are and how they got here. They fall in and out of love, profess loyalty then break faith, and chase something they don't understand into the darkness. Some travel 
alone, others in pairs. Either way, they never know where their rivers are flowing. In hindsight, however, we can view them as fellow pilgrims on a shared journey. Their presence is palpable at the Moonlight Motel, too. Springsteen summons them all for a ghostly reunion, and a final shot of consecrated Jack before closing time, in the foul rag and bone shop of the hungry heart.

GRALEY HERREN is Professor of English at Xavier University in Cincinnati. He has published books on Samuel Beckett and Don DeLillo.

\section{Notes}

1. This maxim is attributed to Heraclitus by Plato in the Cratylus: "Heraclitus, I believe, says that all things pass and nothing stays, and comparing existing things to the flow of a river, he says you could not step twice into the same river." Plato in Twelve Volumes: With an English Translation, vol. 4: Cratylus/ Parmenides/Greater Hippias/Lesser Hippias, ed. and trans. Harold North Fowler (Cambridge, Mass.: Loeb Classical Library/Harvard University Press, 1935), 402a.

2. Eliot asserts in "Tradition and the Individual Talent": "What happens when a new work of art is created is something that happens simultaneously to all the works of art which preceded it. The existing monuments form an ideal order among themselves, which is modified by the introduction of the new (the really new) work of art among them. The existing order is complete before the new work arrives; for order to persist after the supervention of novelty, the whole existing order must be, if ever so slightly, altered; and so the relations, proportions, values of each work of art toward the whole are readjusted." T. S. Eliot, "Tradition and the Individual Talent," The Egoist 6, no. 4 (September 1919): 54. See also https://www.poetryfoundation.org/articles/69400/tradition-and-the-individual-talent (accessed February 22, 2020).

3. Bruce Springsteen, Born to Run (New York: Simon \& Schuster, 2016), 275.

4. All quotations from Springsteen's song lyrics are taken from Eddy Wehbe's indispensable website Bruce Springsteen Lyrics (https://www.springsteenlyrics. $\operatorname{com} /$ ).

5. Clinton Heylin hypothesizes that "Stolen Car" "may have begun as a continuation" of "Hungry Heart." He notes that an early variant lyric of "Stolen Car" recycles the same central image: "We got married and promised never to part / Then I fell victim to a hungry heart." Clinton Heylin, E Street Shuffle: The Glory Days of Bruce Springsteen (New York: Viking, 2012), 196.

6. Springsteen, Born to Run, 272-73.

7. Springsteen, Born to Run, 349 . 
8. During live performances of his version of "One Step Up," Welsh singer Martyn Joseph provides an extended commentary on what makes this song so powerful. Joseph told interviewer Irwin H. Streight: "When I occasionally break down 'One Step Up' onstage to go a little deeper into the song, well, that gets a huge reaction, but I have no idea if that was what Bruce was thinking when he wrote it. I am trying to point out that this is more than just a bar song. If you think it is just a nice little moving country song about a guy in a bar whose marriage has broken up, then, no, I think you're wrong: there is so much more going on. I think the song sums up the human condition." Irwin H. Streight, "The Welsh Springsteen: An Interview with Martyn Joseph," in Long Walk Home, ed. Jonathan Cohen and June Skinner Sawyers, 119-27 (New Brunswick, N.J.: Rutgers University Press, 2019), 121-22). For a recording of Joseph's commentary, see the YouTube video “Martin Joseph-'One Step Up' (Bruce Springsteen) @ Concerts At Our House," https://www.youtube.com/watch?v=rZjNHqxKJWw.

9. See "Highway 29" lyrics page, spoken introduction, https://www.springsteenlyrics.com/lyrics.php?song=highway29_1996-04-24.

10. Springsteen reinforces the album's debts to Westerns by directing and starring in the movie Western Stars: part concert footage, part documentary, and part short-film vignettes inspired by the songs and their cinematic antecedents. For a wide-ranging discussion of Springsteen's aims and influences on both album and film, see his interview with Chris Jordan, "Bruce Springsteen Talks Personal Trilogy, John Wayne and 'Western Stars': The Transcript.” Asbury Park Press, October 21, 2019, https://www.app.com/story/entertainment/ music/2019/10/21/springsteen-western-stars-dark-days-mental-health-andenduring-love/3942629002/\#.

11. William Butler Yeats, "The Circus Animals' Desertion," in The Collected Works of W. B. Yeats, Volume I: The Poems, 2nd ed., ed. Richard J. Finneran, 355-56 (New York: Scribner, 1997), 355.

\section{Works Cited}

Eliot, T. S. "Tradition and the Individual Talent." The Egoist 6, no. 4 (September 1919): 54

Heylin, Clinton. E Street Shuffle: The Glory Days of Bruce Springsteen छ the E Street Band. New York: Viking, 2012.

Jordan, Chris. "Bruce Springsteen Talks Personal Trilogy, John Wayne and 'Western Stars': The transcript.” Asbury Park Press, October 21, 2019. https://www.app.com/ story/entertainment/music/2019/10/21/springsteen-western-stars-dark-daysmental-health-and-enduring-love/3942629002/. Accessed February 22, 2020.

“Martin Joseph-'One Step Up' (Bruce Springsteen) @ Concerts At Our House." YouTube, December 13, 2011. https://www.youtube.com/watch?v=rZjNHqxKJWw. Accessed February 22, 2020.

Plato. Cratylus. In Plato in Twelve Volumes: With an English Translation, vol. 4: Cratylus/Parmenides/Greater Hippias/Lesser Hippias, edited and translated 
by Harold North Fowler. Cambridge, Mass.: Loeb Classical Library/Harvard University Press, 1935.

Springsteen, Bruce. Born to Run. Simon \& Schuster, 2016.

—_. "Highway 29." The Ghost of Tom Joad. Columbia Records, 1995.

—_. "Hitch Hikin.” Western Stars. Columbia Records, 2019.

—_. "Hungry Heart." The River. Columbia Records, 1980.

—_. "Moonlight Motel." Western Stars. Columbia Records, 2019.

—. "Stolen Car." The River. Columbia Records, 1980.

—_. "One Step Up." Tunnel of Love. Columbia Records, 1987.

Streight, Irwin H. "The Welsh Springsteen: An Interview with Martyn Joseph." Long Walk Home, ed. Jonathan Cohen and June Skinner Sawyers, 119-27. New Brunswick, N.J.: Rutgers University Press, 2019.

Whebe, Eddy. Springsteen Lyrics. https://www.springsteenlyrics.com/index.php. Accessed January 18, 2020.

Yeats, W. B. “The Circus Animals' Desertion.” In The Collected Works of W. B. Yeats, Volume I: The Poems. Second Edition. Edited by Richard J. Finneran, 355-56. New York: Scribner, 1997. 